\title{
FTIR Spectroscopic Characterization of Almond Varieties (Prunus dulcis) from Himachal Pradesh (India)
}

\author{
Sunil Sharma* and Neeraj
}

\author{
Department of Agriculture and Environmental Sciences, National Institute of Food \\ Technology Entrepreneurship and Management, Kundli, Sonepat India
}

*Corresponding author

Keywords

Almonds, FTIR, Katha,

Thin Shell, Dhebar,

Telangi selection,

Functional groups

Article Info

Accepted:

10 April 2018

Available Online:

10 May 2018

\section{A B S T R A C T}

Almond is known for its nutritive value and is popularly consumed in India after overnight soaking. It is rich in lipid profile, polyphenols content followed by vitamin-E and also found rich in minerals like magnesium, potassium, calcium and phosphorus which play important biological roles in the human body. There are different types of almond varieties present in India which include commercial types and wild types. The present study aims at Fourier Transform Infrared Spectroscopy (FTIR) characterisation of the four popular varieties of almond from Kinnaur, Himachal Pradesh (India) viz. Katha, Thin Shell, Dhebar and Telangi Selection. FTIR spectroscopic studies will enable us to assess the nutritionally important functional groups present in almonds which in turn will support the variety specific compositional chemistry and nutritional characterization of selected almond varieties. FTIR of four different varieties of almonds viz. Katha, Thin shell, Dhebar and Telangi Selection showed characteristic peak values referring the presence of diverse class of functional groups like esters, amines, carboxylic acids, aromatics, phenols and amides.

\section{Introduction}

Almond belongs to Rosaceae family which also includes prunes, apple, raspberries and pears. Almond (Prunus dulcis) is one of the nutritive tree nuts with a rich lipid profile, polyphenols content followed by vitamin $\mathrm{E}$ and also found rich in minerals like magnesium, potassium, calcium and phosphorus which plays an important biological roles in the human body.

In humans it lowers down the total LDL cholesterol if half of the daily diet intake is replaced by nuts (Abbey et al., 1994). Almond and the other tree nuts are called as nutrient dense food due to the presence of lipids and proteins in them (King et al., 2008) and therefore of vital importance for the human health and makes it a potential ingredient in nutrition based food industry. Besides this they also provide a healthy nutritional profile by providing dietary fibre, Vitamin-E, phytosterols, micronutrients which leads to diverse benefits in terms of blood lipid profile, cardio-protective benefits (Griel and KrisEtherton, 2006; Esfahlan et al., 2010; Richardson et al., 2009; Jenkins et al., 2008; Coates and Howe, 2007, Esfandan, et al., 2010). 
Diverse ancient medical and scientific records of Greeks, Persians, Chinese and Indian ayurveda describes about properties of sweet almonds and their role in nourishing the health and having the brain strengthening properties (Albala, 2009). Almonds are mainly grown in Jammu and Kashmir followed by Himachal Pradesh and some parts of the Uttarakhand (APEDA database). Globally, USA is the leading producer in the world for almond production and its production is mainly confined to the California (Bolling et al., 2010). The environmental conditions like variability in the climate impacts the composition, nutritional value followed by the health attributes in almonds (Jahanban et al., 2010; Piscopo et al., 2010). Almonds are rich in monounsaturated fatty acids and possess $21 \%$ protein followed by $4 \%$ carbohydrates (Mexis and Kontominas, 2010). A latest FTIR study on the medicinal varieties of almonds (chinese origin) exhibited strong presence of alkene functional group, weak aldehyde groups followed by medium intensity functional groups like alkanes indicative of its pharmacological and medicinal significance (Cheng et al., 2017). Various studies have also indicated that the sweet flavours and bitter flavours are inheritable traits in almond (Dicenta and Garcia, 1993 and Wirthensohn et al., 2008). The bitter almonds possess (3-9\%) of amygdalin which is a diglucoside by nature and on enzymatic hydrolysis, it leads to the development of hydrocyanic acid and benzaldehyde. Chaouali et al., (2013) also reported about presence of toxic levels of cyanide in almonds. Thus bitter almonds are used for extracting flavors. In current pretext, very limited information is available about the varietal and nutritional characterization of indigenous (Indian origin) almond varieties.

Since, the scientific information regarding these underexplored varieties (Katha, Dhebar, Telangi Selection, Thin Shell) of Himachal
Pradesh is limited, the aim of current study is an attempt to identify the of functional groups of these selected almond varieties. The information obtained as a result of this study could be beneficial to food and nutraceuticals industries for the new product development, extraction of flavours, medicinal compounds, etc.

\section{Materials and Methods}

The four local almond varieties namely Katha, Thin shell, Dhebar, and Telangi Selection were procured from Regional Horticultural Research and Training Station (Dr Y.S. Parmar University of Horticulture and Forestry, Solan), Sharbo, Distt. Kinnaur Himachal Pradesh. The samples were prepared immediately before analysis by grinding them in an electric grinder followed by sieving through $1 \mathrm{~mm}$ sieve to achieve homogeneity. The homogenous samples were subjected to FTIR analysis using FTIR (Cary 630 FTIR Spectrometer, Agilent Technologies). A minute quantity of freshly ground sample was used on the ATR crystal area $(1 \times 1 \mathrm{~mm})$ ensuring the complete coverage of crystal area for error free analysis. The clamp over the sample was tightened for better functioning of the instrument. Transmittance mode was used for recording the spectra. Crystal was made clear by using acetone followed by its drying by a soft tissue paper before placing the subsequent samples. The interpretation of the FTIR results has been done on the basis of reference information as compiled by Coates (2000) and García et al., (2013).

\section{Results and Discussion}

FTIR analysis of four almond varieties native of the district Kinnaur (Himachal Pradesh) was done. The FTIR results obtained regarding spectra analysis of selected almond varieties have been presented in the Table 1 (A-D) and the peaks obtained for each variety 
have also been presented in Figure 1-4, respectively. The Plates 1(A) and 1(B) depict the varieties under study.

The important constituents of almonds indicating presence of specific functional groups are proteins, carbohydrates, alcohol, esters and water. The spectra of each variety showed specific bands indicating the presence of specific functional groups. The results presented are among the first of its kind report on FTIR spectroscopic analysis of the selected varieties from Himachal Pradesh.

In Katha variety (Table 1A) and as shown in the Figure 1, the different bands falling between the different spectra are presented. In case of spectra region $3000-3200 \mathrm{~cm}^{-1}$ shows the presence of band $3279 \mathrm{~cm}^{-1}$ which indicates the presence of Normal "Polymeric" $\mathrm{OH}$ group (Alcohol and hydroxyl compounds group frequencies) is also supported by the previous studies done by Thygesen et al., (2003) and Subramanian et al., (2009).

Besides this, the latest study done on the Chinese medicinal almonds also showed the high intensity peaks for alkenes (Cheng et al., 2017) and therefore confirms our results. Further, it is also to mention that the values above $3000 \mathrm{~cm}^{-1}$ indicates the presence of unsaturated or aromatic groups (Medial cis- or trans-C-H stretch) whereas the values below $3000 \mathrm{~cm}^{-1}$ indicate the prevalence of aliphatic groups (C-H Group). The presence of aliphatic groups have also been reported by Sanahuja et al., (2009), Hern'andez and Zacconi (2009), Klaypradit et al., (2010).

The range $2800-3000 \mathrm{~cm}^{-1}$ spectra region showed the presence of two bands, one having the frequency $2923 \mathrm{~cm}^{-1}$ and $2855 \mathrm{~cm}^{-1}$ which are assigned for the presence of Methylene C$\mathrm{H}$ asymmetric/symmetric stretch (Saturated aliphatic alkane/alkyl group frequencies). The similar results were obtained by Hern'andez and Zacconi (2009); Maqsood and Benjakul
(2010). Cheng et al., (2017) also reported medium intensity peaks for alkane functional group in their study on medicinal almonds in China.

A sharp peak having frequency $1631 \mathrm{~cm}^{-1}$ could be observed between the frequency range of $1600-1800 \mathrm{~cm}^{-1}$ which indicated the presence of amides. The results are supported with the findings of Thygesen et al., (2003), Subramanian et al., (2009) and there is another peak within the same frequency range at $1742 \mathrm{~cm}^{-1}$ which indicates the presence of Carbonyl $\mathrm{C}=\mathrm{O}$ functional group frequencies of triglyceride esters and the result is supported with finding of Sanahuja et al., (2009). In case of spectra region falling in range of 1400$1600 \mathrm{~cm}^{-1}$ shows presence of peak frequencies $1536 \mathrm{~cm}^{-1}$ which indicates the presence of Aromatic nitro compounds (Simple hetero-oxy compounds). The results are supported by the studies undertaken by Martinez et al., (2003).

The frequency range $1200-1400 \mathrm{~cm}^{-1}$ showed three peaks wherein peaks at $1396 \mathrm{~cm}^{-1}$ and $1314 \mathrm{~cm}^{-1}$ indicated the presence of Carboxylates (Carboxylic acid salts); Carbonyl compound group frequencies whereas peak at $1237 \mathrm{~cm}^{-1}$ is related to the presence of Aromatic ethers (Oxy compounds group frequencies. The studies conducted by Zahm et al., (2011) and Dimick et al., (1983) also indicate the presence of such compounds in nuts and fruits.

Another frequency band of $1041 \mathrm{~cm}^{-1}$ was found between the frequency ranges 1000$1200 \mathrm{~cm}^{-1}$ which indicated the presence of Primary amine followed by presence of aliphatic phosphates (P-O-C stretch) grouped under simple hetero-oxy compounds as indicated by peak at $998 \mathrm{~cm}^{-1}$ in the spectral frequency range of $800-1000 \mathrm{~cm}^{-1}$. Presence of such compounds has also been reported by Maga and Katz (2012) and Lott et al., (2000) in their respective studies. 
Table.1A FTIR spectroscopy results of Katha variety

\begin{tabular}{|c|c|c|c|c|}
\hline \multicolumn{5}{|c|}{ Katha Almonds } \\
\hline $\begin{array}{l}\text { SI } \\
\text { No. }\end{array}$ & $\begin{array}{l}\text { Spectral } \\
\text { frequency range }\end{array}$ & $\begin{array}{l}\text { Peak } \\
\text { values }\end{array}$ & Origin of Peak & Reference \\
\hline 1. & $3200-3400$ & 3279 & $\begin{array}{l}\text { Normal "Polymeric" OH group (Alcohol and } \\
\text { hydroxyl compounds group frequencies) }\end{array}$ & $\begin{array}{l}\text { Thygesen } \text { et al., (2003), } \\
\text { Subramanian } \text { et al., (2009) }\end{array}$ \\
\hline 2. & $2800-3000$ & 2923 & $\begin{array}{l}\text { Methylene C-H asymmetric/symmetric stretch } \\
\text { (Saturated aliphatic alkane/alkyl group frequencies) }\end{array}$ & $\begin{array}{l}\text { Hernandez and Zacconi`(2009), } \\
\text { Maqsood and Benjakul (2010) }\end{array}$ \\
\hline 3. & $2800-3000$ & 2855 & $\begin{array}{l}\text { Methylene C-H asymmetric/symmetric stretch } \\
\text { (Saturated aliphatic alkane/alkyl group frequencies) }\end{array}$ & $\begin{array}{l}\text { Hernandez and Zacconi`(2009), } \\
\text { Maqsood and Benjakul (2010) }\end{array}$ \\
\hline 4. & $1600-1800$ & 1631 & Amide & $\begin{array}{l}\text { Thygesen et al., (2003), } \\
\text { Subramanian et al., (2009) }\end{array}$ \\
\hline 5. & $1600-1800$ & 1742 & $\begin{array}{l}\text { Carbonyl } \mathrm{C}=\mathrm{O} \text { functional group frequencies of } \\
\text { triglyceride esters }\end{array}$ & Sanahuja et al., (2009) \\
\hline 6. & $1400-1600$ & 1536 & $\begin{array}{l}\text { Aromatic nitro compounds (Simple hetero-oxy } \\
\text { compounds) }\end{array}$ & Martinez et al., (2003) \\
\hline 7. & $1200-1400$ & 1396 & $\begin{array}{l}\text { Carboxylates (Carboxylic acid salts); Carbonyl } \\
\text { compound group frequencies }\end{array}$ & Zahm et al., (2011) \\
\hline 8. & $1200-1400$ & 1314 & $\begin{array}{l}\text { Carboxylates (Carboxylic acid salts); Carbonyl } \\
\text { compound group frequencies }\end{array}$ & Zahm et al., (2011) \\
\hline 9. & $1200-1400$ & 1237 & $\begin{array}{l}\text { Aromatic ethers (Oxy compounds group } \\
\text { frequencies) }\end{array}$ & Dimick et al., (1983) \\
\hline 10. & $1000-1200$ & 1041 & Primary amine & Maga and Katz. (2012) \\
\hline 11. & $800-1000$ & 998 & $\begin{array}{l}\text { Aliphatic phosphates (P-O-C stretch) grouped under } \\
\text { simple hetero-oxy compounds }\end{array}$ & Lott et al., (2000) \\
\hline
\end{tabular}

Table.1B FTIR spectroscopy results of thin shell variety

\begin{tabular}{|c|c|c|c|c|}
\hline \multicolumn{5}{|c|}{ Thin Shell Almonds } \\
\hline $\begin{array}{l}\text { SI } \\
\text { No. }\end{array}$ & $\begin{array}{l}\text { Spectral } \\
\text { frequency range }\end{array}$ & $\begin{array}{l}\text { Peak } \\
\text { values }\end{array}$ & Origin of Peak & Reference \\
\hline$\overline{1 .}$ & $3200-3400$ & 3278 & $\begin{array}{l}\text { Normal "Polymeric" OH group(Alcohol and hydroxyl } \\
\text { compounds group frequencies) }\end{array}$ & $\begin{array}{l}\text { Thygesen } \text { et al., (2003), } \\
\text { Subramanian } \text { et al., (2009) }\end{array}$ \\
\hline 2. & 2800-3000 & 2923 & $\begin{array}{l}\text { Methylene C-H asymmetric/symmetric } \\
\text { stretch(Saturated aliphatic alkane/alkyl group } \\
\text { frequencies) }\end{array}$ & $\begin{array}{l}\text { Hernandez and Zacconi } \\
\text { (2009), Maqsood and } \\
\text { Benjakul (2010) }\end{array}$ \\
\hline 3. & $2800-3000$ & 2854 & $\begin{array}{l}\text { Methylene C-H asymmetric/symmetric } \\
\text { stretch(Saturated aliphatic alkane/alkyl group } \\
\text { frequencies) }\end{array}$ & $\begin{array}{l}\text { Hernandez and Zacconi' } \\
\text { (2009), Maqsood and } \\
\text { Benjakul (2010) }\end{array}$ \\
\hline 4. & $1600-1800$ & 1632 & Amide & $\begin{array}{l}\text { Thygesen et al., (2003), } \\
\text { Subramanian } \text { et al., (2009) }\end{array}$ \\
\hline 5. & $1600-1800$ & 1743 & Ester (Carbonyl compound group frequencies) & Sanahuja et al., (2009) \\
\hline 6. & $1400-1600$ & 1540 & $\begin{array}{l}\text { Aliphatic Nitro compounds (Simple hetero-oxy } \\
\text { compounds) }\end{array}$ & Martinez et al., (2003) \\
\hline 7. & $1200-1400$ & 1397 & $\begin{array}{l}\text { Carboxylates (Carboxylic acid salts) Carbonyl } \\
\text { compound group frequencies }\end{array}$ & Zahm et al., (2011) \\
\hline 8. & $1200-1400$ & 1237 & Aromatic ethers (Oxy compounds group frequencies) & Dimick et al., (1983) \\
\hline 9. & $1000-1200$ & 1040 & Primary amine & Maga and Katz. (2012) \\
\hline 10. & $800-1000$ & 993 & $\begin{array}{l}\text { Aliphatic phosphates (P-O-C stretch) grouped under } \\
\text { simple hetero-oxy compounds }\end{array}$ & Lott et al., (2000) \\
\hline
\end{tabular}


Table.1C FTIR spectroscopy results of Dhebar variety

\begin{tabular}{|c|c|c|c|c|}
\hline \multicolumn{5}{|c|}{ Dhebar Almonds } \\
\hline $\begin{array}{l}\text { SI } \\
\text { No. }\end{array}$ & $\begin{array}{l}\text { Spectral } \\
\text { frequency range }\end{array}$ & $\begin{array}{l}\text { Peak } \\
\text { values }\end{array}$ & Origin of Peak & Reference \\
\hline 1. & $3200-3400$ & 3279 & $\begin{array}{l}\text { Normal "Polymeric" OH group (Alcohol } \\
\text { and hydroxyl compounds group } \\
\text { frequencies) }\end{array}$ & $\begin{array}{l}\text { Thygesen } \text { et al., (2003), } \\
\text { Subramanian } \text { et al., (2009) }\end{array}$ \\
\hline 2. & $2800-3000$ & 2923 & $\begin{array}{l}\text { Methylene C-H asymmetric/symmetric } \\
\text { stretch(Saturated aliphatic alkane/alkyl } \\
\text { group frequencies) }\end{array}$ & $\begin{array}{l}\text { Hernandez and Zacconi } \\
\text { (2009), Maqsood and } \\
\text { Benjakul (2010) }\end{array}$ \\
\hline 3. & $2800-3000$ & 2854 & $\begin{array}{l}\text { Methylene C-H asymmetric/symmetric } \\
\text { stretch (Saturated aliphatic alkane/alkyl } \\
\text { group frequencies) }\end{array}$ & $\begin{array}{l}\text { Hernandez and Zacconi } \\
\text { (2009), Maqsood and } \\
\text { Benjakul (2010) }\end{array}$ \\
\hline 4. & $1600-1800$ & 1631 & Amide & $\begin{array}{l}\text { Thygesen } \text { et al., (2003), } \\
\text { Subramanian } \text { et al., (2009) }\end{array}$ \\
\hline 5. & $1600-1800$ & 1743 & $\begin{array}{l}\text { Ester (Carbonyl compound group } \\
\text { frequencies) }\end{array}$ & Sanahuja et al., (2009) \\
\hline 6. & $1400-1600$ & 1536 & $\begin{array}{l}\text { Aromatic nitro compounds (Simple hetero- } \\
\text { oxy compounds) }\end{array}$ & Martinez et al., (2003) \\
\hline 7. & $1400-1600$ & 1400 & Phenol (hydroxyl compounds) & Bolling et al., (2011) \\
\hline 8. & $1400-1200$ & 1237 & $\begin{array}{l}\text { Aromatic ethers (Oxy compounds group } \\
\text { frequencies) }\end{array}$ & Dimick et al., (1983) \\
\hline 9. & $1000-1200$ & 1043 & Primary amine (CN stretch) & Maga and Katz. (2012) \\
\hline
\end{tabular}

Table.1D FTIR spectroscopy results of Telangi selection variety

\begin{tabular}{|c|c|c|c|c|}
\hline \multicolumn{5}{|c|}{ Telangi Selection Almonds } \\
\hline SI No. & $\begin{array}{l}\text { Spectral } \\
\text { frequency range }\end{array}$ & $\begin{array}{l}\text { Peak } \\
\text { values }\end{array}$ & Origin of Peak & Reference \\
\hline 1. & $3200-3400$ & 3279 & $\begin{array}{l}\text { Normal "Polymeric" OH group (Alcohol and } \\
\text { hydroxyl compounds group frequencies) }\end{array}$ & $\begin{array}{l}\text { Thygesen et al., (2003), } \\
\text { Subramanian et al., (2009). }\end{array}$ \\
\hline 2. & $2800-3000$ & 2855 & $\begin{array}{l}\text { Methylene C-H asymmetric/symmetric } \\
\text { stretch (Saturated aliphatic alkane/alkyl } \\
\text { group frequencies) }\end{array}$ & $\begin{array}{l}\text { Hernandez and Zacconi' } \\
\text { (2009), Maqsood and } \\
\text { Benjakul (2010) }\end{array}$ \\
\hline 3. & $2800-3000$ & 2923 & $\begin{array}{l}\text { Methylene C-H asymmetric/symmetric } \\
\text { stretch (Saturated aliphatic alkane/alkyl } \\
\text { group frequencies) }\end{array}$ & $\begin{array}{l}\text { Hernandez and Zacconi } \\
\text { (2009), Maqsood and } \\
\text { Benjakul (2010) }\end{array}$ \\
\hline 4. & $1600-1800$ & 1743 & $\begin{array}{l}\text { Ester (Carbonyl compound group } \\
\text { frequencies) }\end{array}$ & Sanahuja et al., (2009) \\
\hline 5. & $1600-1800$ & 1633 & $\begin{array}{l}\text { Amide (Carbonyl compound group } \\
\text { frequencies) }\end{array}$ & $\begin{array}{l}\text { Thygesen et al., (2003), } \\
\text { Subramanian } \text { et al., (2011) }\end{array}$ \\
\hline 6. & $1400-1600$ & 1402 & $\begin{array}{l}\text { Carboxylates (Carboxylic acid salts), } \\
\text { Carbonyl compound group frequencies }\end{array}$ & Zahm et al., (2011) \\
\hline 7. & $1400-1600$ & 1541 & $\begin{array}{l}\text { Aliphatic Nitro compounds (Simple hetero- } \\
\text { oxy compounds) }\end{array}$ & Martinez et al., (2003) \\
\hline 8. & $1200-1400$ & 1237 & $\begin{array}{l}\text { Aromatic ethers (Oxy compounds group } \\
\text { frequencies) }\end{array}$ & Dimick et al., (1983) \\
\hline 9. & $1000-1200$ & 1038 & Primary amine & Maga and Katz. (2012) \\
\hline 10. & $800-1000$ & 992 & $\begin{array}{l}\text { Aliphatic or Aromatic phosphates (P-O-C } \\
\text { stretch) Simple hetero-oxy compounds }\end{array}$ & Lott et al., (2000) \\
\hline
\end{tabular}




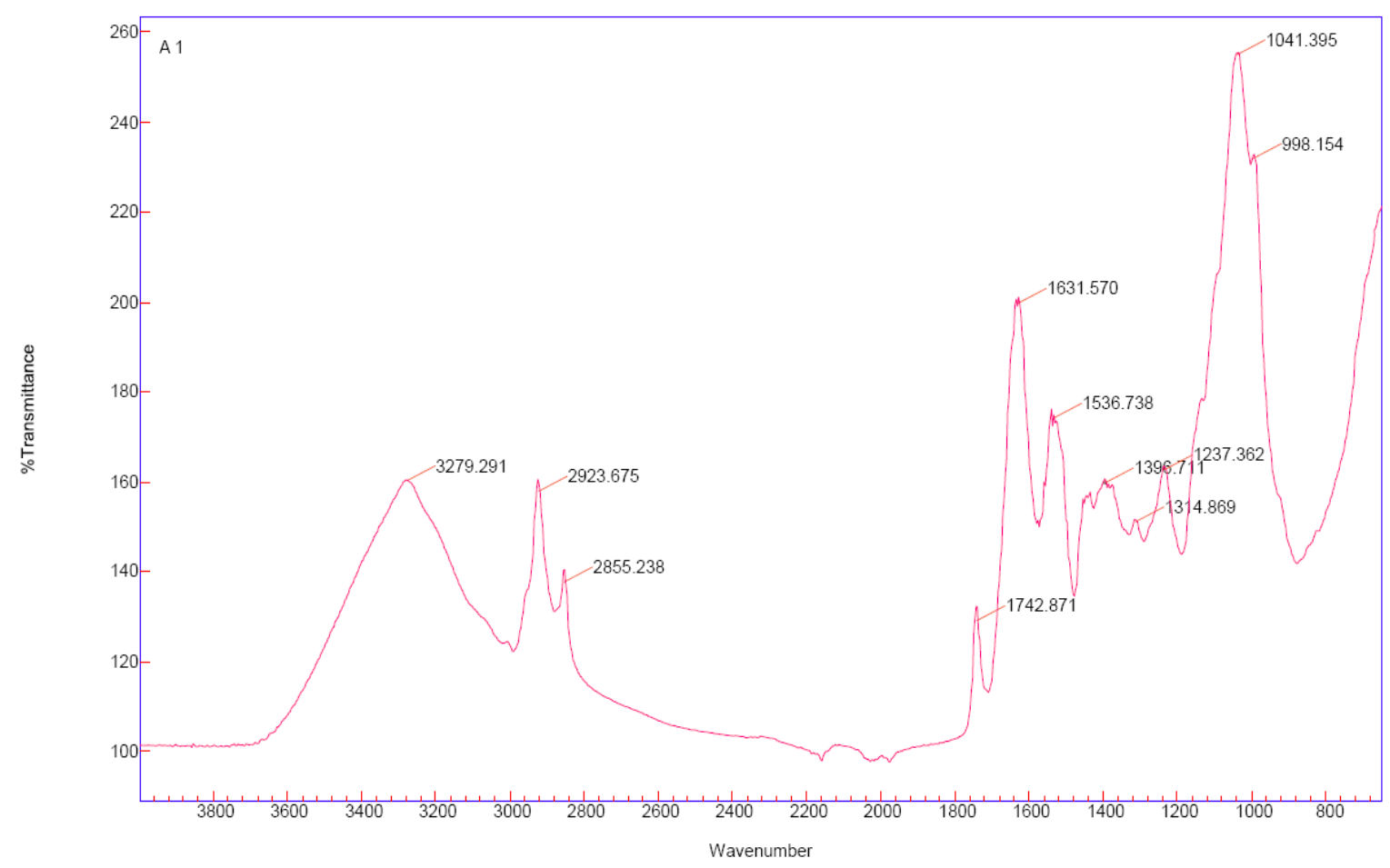

Fig.1 FTIR spectrum of Katha variety

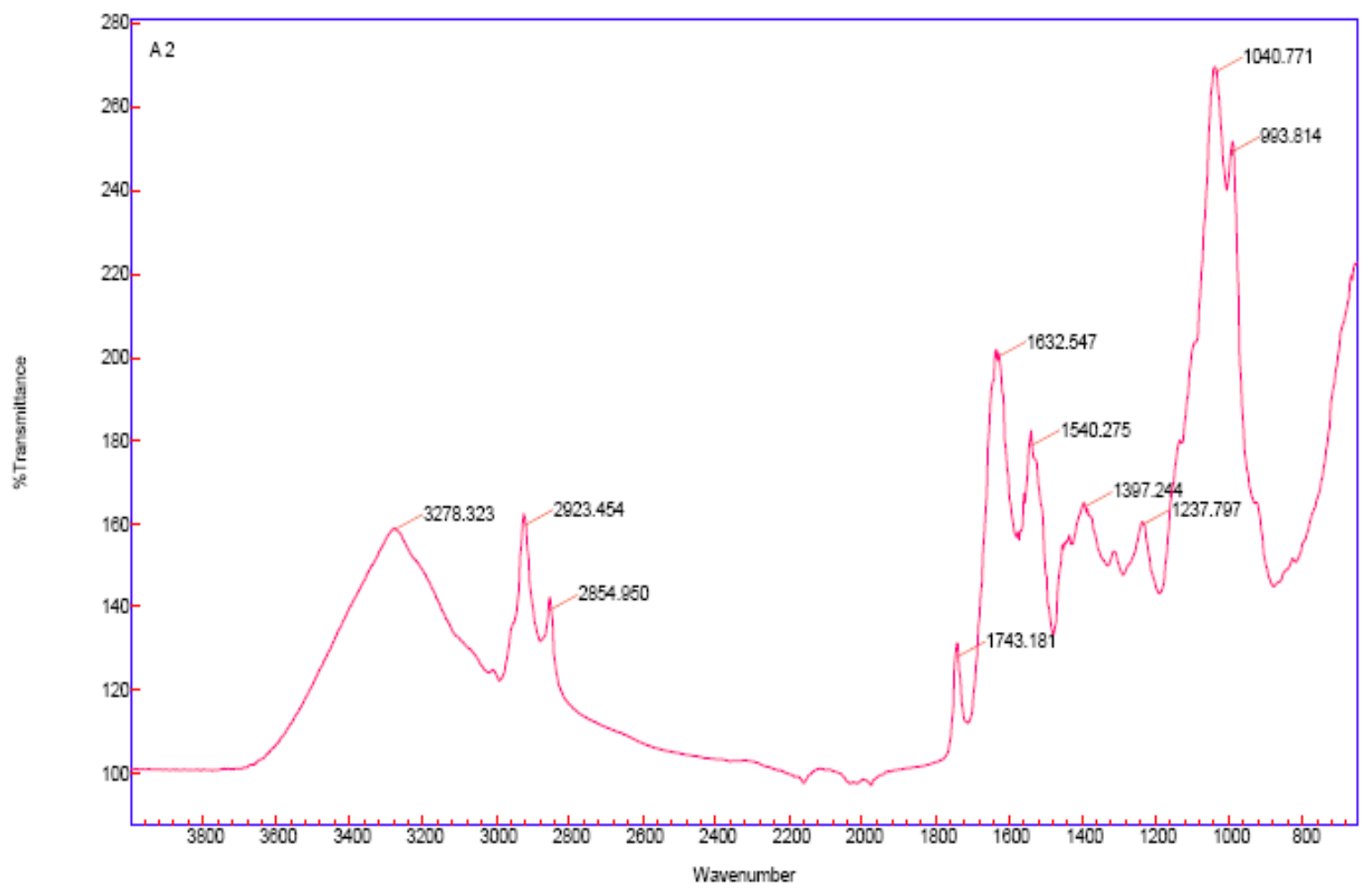

Fig.2 FTIR spectrum of thin shell 
Int.J.Curr.Microbiol.App.Sci (2018) 7(5): 887-898

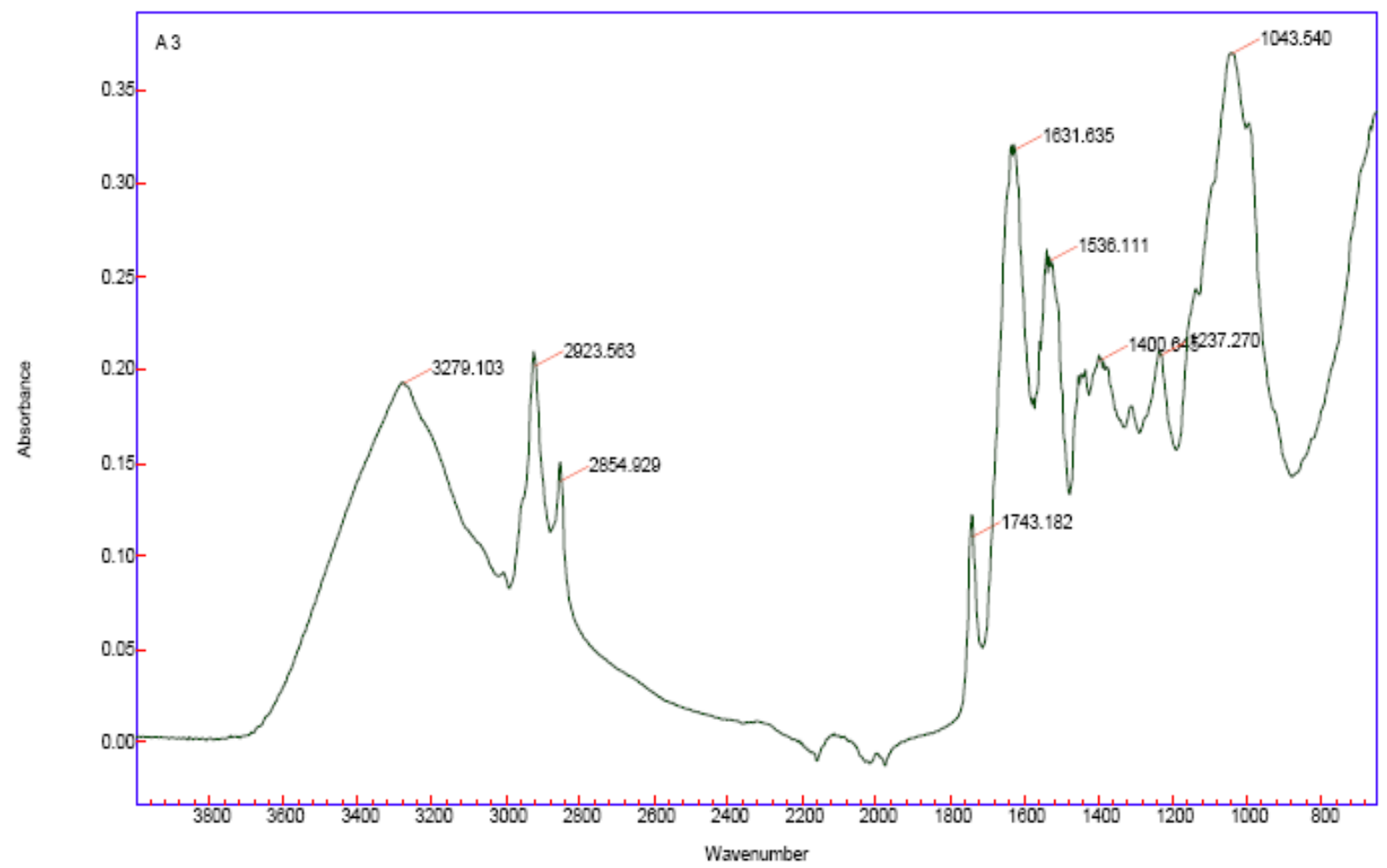

Fig.3 FTIR spectrum of Dhebar variety

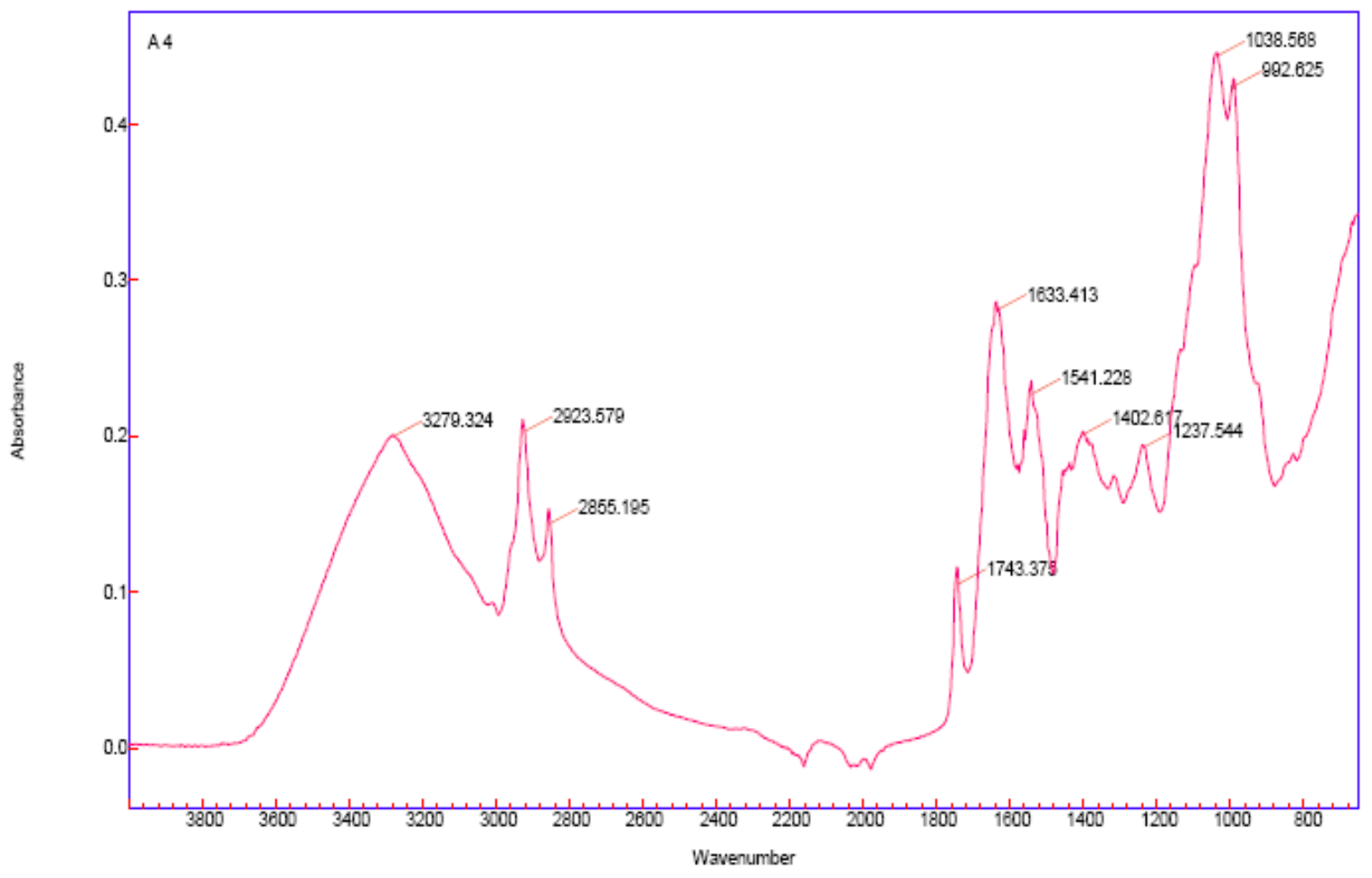

Fig.4 FTIR spectrum of Telangi selection variety 
Plate.1 (A) Almond varieties under study - (Without Shell)

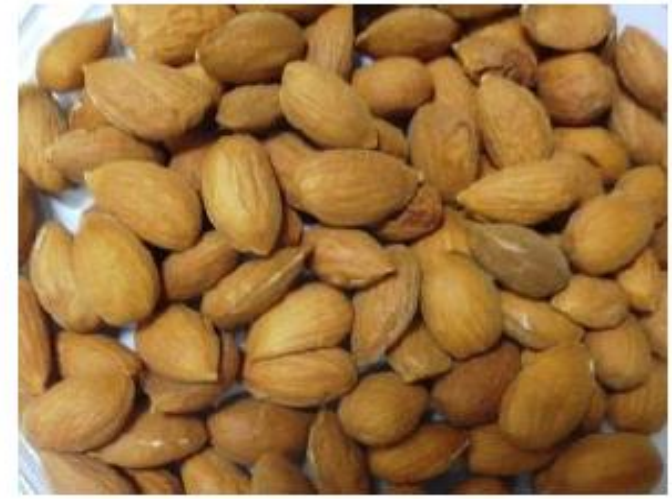

1. Katha

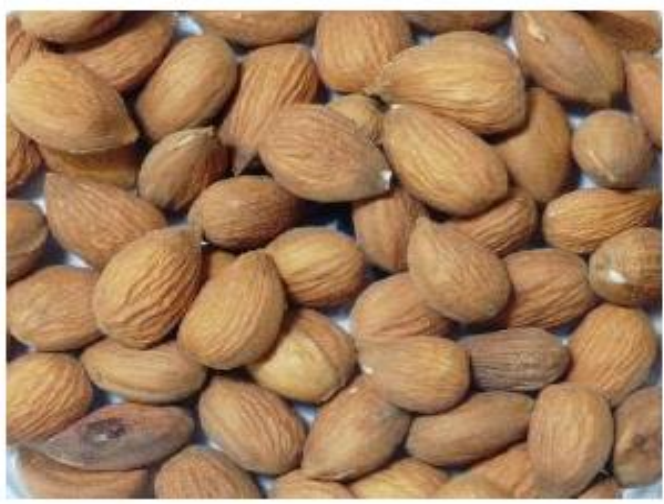

3. Dhebar

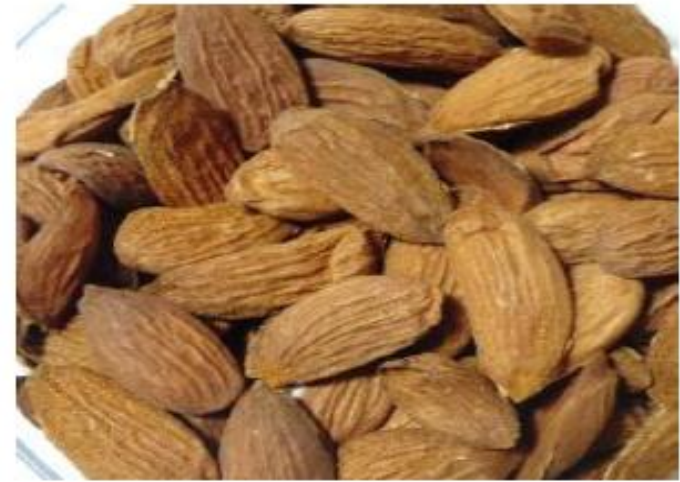

2. Thin Shell

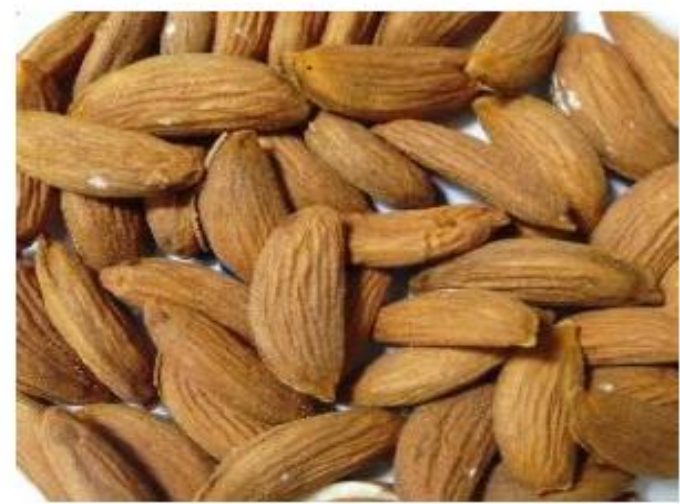

4. Telangi selection

Plate.1 (B) Almond varieties under study - (With Shell)

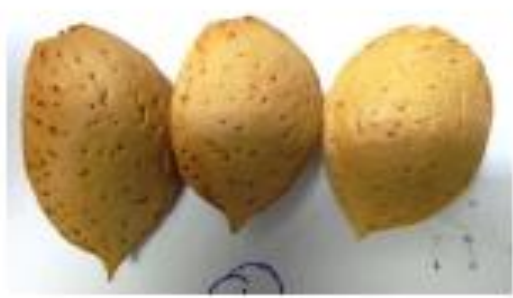

1. Katha

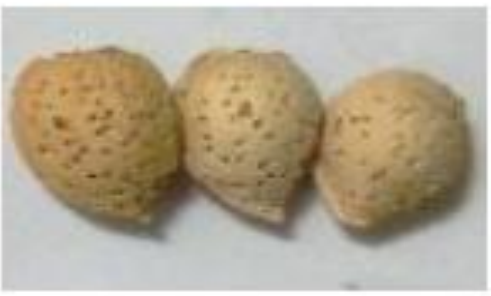

3. Dhebar

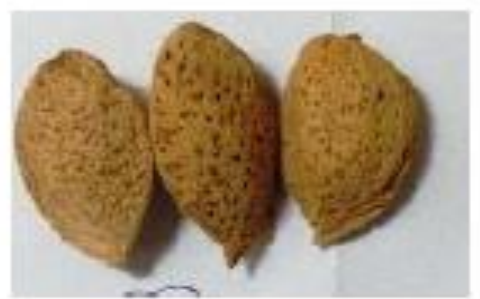

\section{Thin Shell}

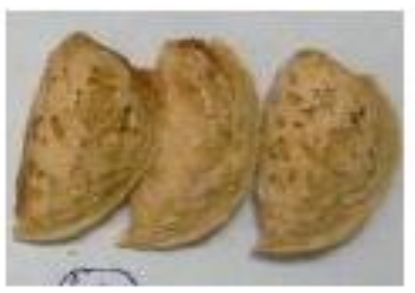

4. Telangi selection 
In thin shell variety (Table 1B and Fig. 2) a distinct peaks at $3278 \mathrm{~cm}^{-1}$ was observed in the spectrum range of $3200-3400 \mathrm{~cm}^{-1}$ indicating the presence of Normal "Polymeric" OH group (alcohol and hydroxyl compounds group frequencies) as previously reported in the studies of Thygesen et al., (2003) and Subramanian et al., (2009).

The two peaks viz. $2923 \mathrm{~cm}^{-1}$ and $2854 \mathrm{~cm}^{-1}$ falling in the spectrum range of $2800-3000 \mathrm{~cm}^{-1}$ indicated the presence of Methylene $\mathrm{C}-\mathrm{H}$ asymmetric/symmetric stretch (Saturated aliphatic alkane/alkyl group frequencies). Such peaks has also been reported in studies conducted by Hernandez and Zacconi' (2009), Maqsood and Benjakul (2010).

A peak having frequency $1743 \mathrm{~cm}^{-1}$ indicated the presence of Carbonyl functional group frequencies of esters and the result is supported with finding of Sanahuja et al., (2009) between the frequency range of $1600-1800 \mathrm{~cm}^{-1}$ wherein the peak at $1632 \mathrm{~cm}^{-1}$ indicated the presence of amides which is supported by the findings of Thygesen et al., (2003) and Subramanian et al., (2009).

The studies of Martinez et al., (2003) indicates the association of nitro compounds with flavours of bitter almonds and in our study we found the presence of a peak $1540 \mathrm{~cm}^{-}{ }^{1}$ in spectral frequency range of $1400-1600 \mathrm{~cm}^{-1}$ which is largely associated with Aliphatic Nitro compounds (Simple hetero-oxy compounds).

The frequency range $1200-1400 \mathrm{~cm}^{-1}$ showed two peaks wherein peak at $1397 \mathrm{~cm}^{-1}$ indicated the presence of Carboxylates (Carboxylic acid salts) and Carbonyl compound group frequencies whereas peak at $1237 \mathrm{~cm}^{-1}$ is related to the presence of Aromatic ethers (Oxy compounds group frequencies). The studies conducted by Zahm et al., (2011) and Dimick et al., (1983) also indicate the presence of such compounds in nuts and fruits, respectively.

Another frequency band of $1040 \mathrm{~cm}^{-1}$ was found between the frequency ranges $1000-1200 \mathrm{~cm}^{-1}$ which indicated the presence of Primary amine followed by presence of aliphatic phosphates (P-O-C stretch) grouped under simple heterooxy compounds as indicated by peak at $993 \mathrm{~cm}^{-1}$ in the spectral frequency range of $800-1000$ $\mathrm{cm}^{-1}$. Presence of such compounds has also been reported by Maga and Katz (2012) in food and Lott et al., (2000) in seeds and fruits, respectively.

FTIR Analysis of Dhebar variety (Table 1C Fig. 3 ) shows that spectrum range of $3200-3400 \mathrm{~cm}^{-1}$ is marked with presence of wave no. $3279 \mathrm{~cm}^{-1}$ which indicates polymeric $\mathrm{O}-\mathrm{H}$ stretch and the same has also been reported by Subramanian et al., (2009) and Thygesen et al., (2003).

In range of $2800-3000 \mathrm{~cm}^{-1}$ lies two wave numbers viz., $2923 \mathrm{~cm}^{-1} 2854 \mathrm{~cm}^{-1}$ which indicated the presence of methylene $\mathrm{C}-\mathrm{H}$ asymmetric/symmetric stretch (Saturated aliphatic alkane/alkyl group frequencies) and is supported by results of studies done in past by Hern'andez and Zacconi (2009) and Maqsood and Benjakul (2010).

In case of peaks lying in the range 1600$1800 \mathrm{~cm}^{-1}$ there are two main peaks $1743 \mathrm{~cm}^{-1}$ and $1631 \mathrm{~cm}^{-1}$. The peak $1631 \mathrm{~cm}^{-1}$ indicates presence of amides while $1743 \mathrm{~cm}^{-1}$ indicates the presence of ester compounds which forms the major components (like oil) in the almonds. The results are supported by the work of Thygesen et al., (2003), Subramanian et al., (2009) and Sanahuja et al., (2009).

The spectrum range of $1400-1600 \mathrm{~cm}^{-1}$ showed presence of $1536 \mathrm{~cm}^{-1}$ wave no. indicating presence of aromatic nitro compounds whereas $1400 \mathrm{~cm}^{-1}$ wave no. indicates the presence of phenols. Aromatic nitro compounds associated with bitter flavour of almond has been mentioned by Martinez et al., (2003) in his work on acute nitrobenzene poisoning. The presence of phenols and its related compounds have also been reported by Bolling et al., (2011).

The spectra range of $1400-1200 \mathrm{~cm}^{-1}$ showed 
peak $1237 \mathrm{~cm}^{-1}$ indicating presence of aromatic ethers (oxy compounds group frequencies). Dimick et al., (1983) also reported presence of such aromatic compounds in his studies on apple flavours. The spectrum range of 1200$1000 \mathrm{~cm}^{-1}$ showed a peak $1043 \mathrm{~cm}^{-1}$ which indicated the presence of primary amine compounds (C-N Stretch). Maga and Katz (2012) have also reported the presence of such compounds (amines) in food.

The FTIR analysis of Telangi selection, (Table 1D Fig. 4), revealed that the first range of spectra $3200-3400 \mathrm{~cm}^{-1}$ with the peak value $3279 \mathrm{~cm}^{-1}$ and indicated the presence of presence of hydroxyl group $(\mathrm{O}-\mathrm{H})$ and the same has been reported in past by Thygesen et al., (2003) and Subramanian et al., (2009).

The other spectrum range of $2800-3000 \mathrm{~cm}^{-1}$ showed peaks viz., $2855 \mathrm{~cm}^{-1}$ and $2923 \mathrm{~cm}^{-1}$, indicative of the presence of methylene $(\mathrm{C}-\mathrm{H})$ asymmetric/symmetric stretch. Similar results have been reported by Hern'andez and Zacconi (2009) and Maqsood and Benjakul (2010).

In the spectral range $1600-1800 \mathrm{~cm}^{-1}$, the presence of peaks $1743 \mathrm{~cm}^{-1}$ and $1633 \mathrm{~cm}^{-1}$ are indicative of the presence of Carbonyl compound group frequencies which are supported by the results obtained by Sanahuja et al., (2009), Thygesen et al., (2003) and Subramanian et al., (2011).

The spectral range of $1400-1600 \mathrm{~cm}^{-1}$ shows a peak as $1402 \mathrm{~cm}^{-1}$ indicating the presence Carboxylates (Carboxylic acid salts) and the other peak at $1541 \mathrm{~cm}^{-1}$ is indicative of the presence of Aliphatic Nitro compounds (Simple hetero-oxy compounds).

In the spectral range of $1200-1400 \mathrm{~cm}^{-1}$, the peak at $1237 \mathrm{~cm}^{-1}$ indicated the presence of aromatic ethers. The studies on apple flavours also find the mention of such aromatic compounds in Rosaceae family (Dimick et al., (1983).

The spectral range of $1000-1200 \mathrm{~cm}^{-1}$ showed a peak values as $1038 \mathrm{~cm}^{-1}$ indicating the presence of primary amines and amines has been reported as part of building blocks of amino acids (Maga and Katz, 2012).

The peak at $992 \mathrm{~cm}^{-1}$ in the spectral range of $800-1000 \mathrm{~cm}^{-1}$ indicated the presence of indicating the presence of aliphatic or aromatic phosphates (P-O-C stretch) grouped under simple hetero-oxy compounds. Presence of such phosphorus related compounds has also been studied by Lott et al., (2000) crop seeds and fruits.

The four varieties considered for the current study viz. Katha, Thin shell, Dhebar and Telangi selection are the local varieties found in the Kinnaur region of Himachal Pradesh. These varieties are considered native to this area and have been traditionally used in the local areas only. Generally most of the compounds in the almonds are similar but the deviations could be there due to the different geographical areas, growth environments and also due to agronomic practices followed in that specific location. Therefore, in order to highlight the nutritional importance of these traditional varieties the FTIR spectroscopic study was conducted to explore the functional groups of biological importance. The results showed characteristic peak values referring the presence of diverse class of functional groups like esters, amines, carboxylic acids, aromatics, phenols and amides.

\section{Acknowledgement}

We are grateful to Regional Horticultural Research and Training Station (Dr Y.S. Parmar University of Horticulture and Forestry, Solan), Sharbo, Distt. Kinnaur, Himachal Pradesh for providing us the samples of these four varieties of almonds to carry out this study.

\section{References}

Abbey, M., Noakes, M., Belling, G. B., and Nestel, P. J. (1994). Partial replacement of saturated fatty acids with almonds or 
walnuts lowers total plasma cholesterol and low-density-lipoprotein cholesterol. American Journal of Clinical Nutrition, 59: 995-999

Agricultural and Processed Food Products Export Development Authority (APEDA): Indian Production of ALMOND. Retrieved March 10, 2018 from: http://apeda.in/agriexchange/India \%20Production/India_Productions.aspx?c at $=$ fruit $\&$ hscode $=1038$

Albala, K. (2009). Almonds along the Silk Road: the exchange and adaptation of ideas from West to East. Petits Propos Culinaires, 88: 19.

Bolling BW, Blumberg JB, Chen CY. (2010). The influence of roasting, pasteurisation, and storage on the polyphenol content and antioxidant capacity of California almond skins. Food Chemistry, 123 (4):1040-47.

Bolling, B. W., Chen, C. Y. O., McKay, D. L., and Blumberg, J. B. (2011). Tree nut phytochemicals: composition, antioxidant capacity, bioactivity, impact factors. A systematic review of almonds, Brazils, cashews, hazelnuts, macadamias, pecans, pine nuts, pistachios and walnuts. Nutrition Research Reviews, 24(2), 244275.

Chaouali, N., Gana, I., Dorra, A., Khelifi, F., Nouioui, A., Masri, W., Belwaer, I., Ghorbel, H. and Hedhili, A. (2013). Potential toxic levels of cyanide in almonds (Prunus amygdalus), apricot kernels (Prunus armeniaca), and almond syrup. ISRN toxicology, 2013.

Cheng, C. S., Can-Jian, W. A. N. G., Liang, J., Chi-Chou, L.A.O., Hua, Z.H.O.U., and Zhang, Z.F. (2017). A new approach for identification of medicinal almonds by Fourier transform infrared spectroscopy and systematic clustering of characteristic peaks. Chinese journal of natural medicines, 15(9): 703-709.

Coates, A. M., and Howe, P. R. (2007). Edible nuts and metabolic health. Current opinion in lipidology, 18(1): 25-30
Coates, J. (2000). Interpretation of infrared spectra, a practical approach. Encyclopedia of analytical chemistry.

Dicenta, F., and García, J. E. (1993). Inheritance of the kernel flavour in almond. Heredity, 70(3): 308.

Dimick, P. S., Hoskin, J. C., and Acree, T. E. (1983). Review of apple flavor-state of the art. Critical Reviews in Food Science \& Nutrition, 18(4), 387-409.

Esfahlan, A. J., Jamei, R., and Esfahlan, R. J. (2010). The importance of almond (Prunus amygdalus L.) and its byproducts. Food chemistry, 120(2): 349360.

García, A. V., Beltrán Sanahuja, A., and Garrigós Selva, M. D. C. (2013). Characterization and classification of almond cultivars by using spectroscopic and thermal techniques. Journal of food science, $78(2)$.

Griel, A. E., and Kris-Etherton, P. M. (2006). Tree nuts and the lipid profile: a review of clinical studies. British Journal of Nutrition, 96(S2): S68-S78.

Hernández, S. A., and Zacconi, F. (2009). Sweet almond oil: extraction, characterization and application. Química Nova, 32(5): 1342-1345.

Jenkins, D. J., Hu, F. B., Tapsell, L. C., Josse, A. R., and Kendall, C. W. (2008). Possible benefit of nuts in type 2 diabetes. The Journal of nutrition, 138(9): 1752S$1756 \mathrm{~S}$.

King, J. C., Blumberg, J., Ingwersen, L., Jenab, M., and Tucker, K. L. (2008). Tree nuts and peanuts as components of a healthy diet. The Journal of nutrition, 138(9): 1736S-1740S.

Klaypradit, W., Kerdpiboon, S., and Singh, R. K. (2011). Application of artificial neural networks to predict the oxidation of menhaden fish oil obtained from Fourier transform infrared spectroscopy method. Food and Bioprocess Technology, 4(3): 475-480.

Lott, J. N., Ockenden, I., Raboy, V., and Batten, G. D. (2000). Phytic acid and phosphorus 
in crop seeds and fruits: a global estimate. Seed Science Research, 10(1), 11-33.

Maga, J. A., and Katz, I. (1978). Amines in foods. Critical Reviews in Food Science and Nutrition, 10(4), 373-403.

Maqsood, S., and Benjakul, S. (2010). Synergistic effect of tannic acid and modified atmospheric packaging on the prevention of lipid oxidation and quality losses of refrigerated striped catfish slices. Food Chemistry, 121(1): 29-38.

Martinez, M. A., Ballesteros, S., Almarza, E., Sanchez de la Torre, C., and Bua, S. (2003). Acute Nitrobenzene Poisoning with Severe Associated Methemoglobinemia: Identification in Whole Blood by GC-FID and GC-MS. Journal of analytical toxicology, 27(4), 221-225.

Mexis, S. F., and Kontominas, M. G. (2010). Effect of oxygen absorber, nitrogen flushing, packaging material oxygen transmission rate and storage conditions on quality retention of raw whole unpeeled almond kernels (Prunus dulcis). LWT-Food Science and Technology, 43(1): 1-11.

Piscopo, A., Romeo, F. V., Petrovicova, B., and Poiana, M. (2010). Effect of the harvest time on kernel quality of several almond varieties (Prunus dulcis (Mill.) DA Webb). Scientia horticulturae, 125(1): 4146.

Richardson, D. P., Astrup, A., Cocaul, A., and Ellis, P. (2009). The nutritional and health benefits of almonds: a healthy food choice. Food Science and Technology Bulletin: Functional Foods, 6(4): 41-50.

Sanahuja, A. B., Moya, M. P., Pérez, S. M., Teruel, N. G., and Carratalá, M. M. (2009). Classification of four almond cultivars using oil degradation parameters based on FTIR and GC data. Journal of the American Oil Chemists' Society, 86 (1), 51-58

Subramanian, A., Harper, W. J., and Rodriguez- Saona, L. E. (2009). Rapid prediction of composition and flavor quality of cheddar cheese using ATRFTIR spectroscopy. Journal of food science, 74(3).

Thygesen, L. G., Løkke, M. M., Micklander, E., and Engelsen, S. B. (2003). Vibrational microspectroscopy of food. Raman vs. FT-IR. Trends in Food Science and Technology, 14(1-2): 50-57.

Wirthensohn, M. G., Chin, W. L., Franks, T. K., Baldock, G., Ford, C. M., and Sedgley, M. (2008). Characterising the flavour phenotypes of almond (Prunus dulcis Mill.) kernels. The Journal of Horticultural Science and Biotechnology, 83(4): 462-468.

Zahm, A., Axel, C., and Speer, K. (2011). Sterols and carboxylic acid-5hydroxytryptamides in selected tree nuts. Polish Journal of Food and Nutrition Sciences, 61(Suppl. 1).

\section{How to cite this article:}

Sunil Sharma and Neeraj. 2018. FTIR Spectroscopic Characterization of Almond Varieties (Prunus dulcis) from Himachal Pradesh (India). Int.J.Curr.Microbiol.App.Sci. 7(05): 887-898. doi: https://doi.org/10.20546/ijcmas.2018.705.108 